\title{
Recent debate and heavy evidence on human origin
}

\author{
Emiliano AGUIRRE
}

Real Academia de Ciencias Exactas, Físicas y Naturales, c/ Valverde 22, 28004 Madrid, Spain

Aguirre, E. 2013. Recent debate and heavy evidence on human origin. [Debate reciente y evidencias sobre el origen humano]. Spanish Journal of Palaeontology, 28 (2), 123-128.

Manuscript received 04 November 2012

Manuscript accepted 09 March 2013

(C) Sociedad Española de Paleontología ISSN 2255-0550

\begin{abstract}
The discovery and the study of Australopithecus sediba has brought the debate between its supporters as the only immediate ancestor of Homo erectus excluding $H$. habilis out of that ancestry as well as any other eventual species of genus Homo, and on the other side the defenders of Homo habilis as the direct ancestor of Homo erectus and following humans. Here the second opinion is supported, with the view that the succession between two species is not instantaneous, the new distinctive traits appearing, generally inherited in several individuals of a single living species, and tribe, coexisting with other individuals bearing primitive traits, until these disappear, even a time after the separation of the groups with different inheritance prevalent. Besides the known sites yielding lithic tools more than 2 Ma old the fossil group of Dmanissi (Rep. Georgia) is a solid proof: one of the earliest tribes of $H$. erectus/ergaster, leaving Africa to Eurasia near 1.8 Ma, including individuals with prevalent traits of $H$. habilis. The climate and environment crises between near 2.5-1.8 Ma ago with harsh aridity in Africa may have influenced such complexes process. In South Africa similar genetic changes may have occurred at a near time, but accompanying evidences of direct effect on the origin of $H$. erectus populations are still missing.
\end{abstract}

Keywords: Malapa, South Africa, Australopithecus sediba, Homo habilis, Homo erectus, Homo origin.

\section{RESUMEN}

El descubrimiento de Australopithecus sediba ha suscitado el debate entre los que sostienen que éste es el antepasado más inmediato de Homo erectus y excluyen a $H$. habilis de esta ascendencia y del género Homo, añadiendo que el antecesor del primer humano sólo puede ser un australopiteco, y quienes siguen defendiendo $H$. habilis como la primera especie del género Homo y el antecesor de H. erectus y todos los demás humanos. Aquí se sostiene la segunda tesis, y que la sucesión entre dos especies no es instantánea, sino que los nuevos rasgos distintivos aparecen y se heredan genéticamente en individuos de una especie coexistiendo con otros anteriores, hasta que terminan los rasgos primitivos en portadores de los nuevos tras el aislamiento reproductivo de éstos. Como prueba, además del desarrollo de industria lítica con $H$. habilis, se menciona la población fósil de Dmanisi, de una de las primeras tribus de $H$. erectus/ergaster, que pasa de África a Eurasia hace cerca de 1,8 Ma, con individuos que aún retenían rasgos de $H$. habilis. Las crisis climáticas y ambientales de hace 2,5 y más de 1,8 Ma con cruda aridez en África pudieron influir en esa compleja evolución. En Sudáfrica pudieron presentarse cambios semejantes en esos o próximos tiempos, pero no hay por ahora registros conocidos del largo proceso.

Palabras clave: Malapa, Sudáfrica, Australopithecus sediba, Homo habilis, Homo erectus, origen de Homo. 


\section{THE MALAPA (NEAR GLADYSVALE) TWO SKELETONS WITH MIXED TRAITS}

Two years ago, a 9 years boy, Mathew Berger, found a fossil clavicle no far from the area near Gladysvale (South Africa) where his father, Prof. Lee R. Berger paleoanthropologist of the Witwatersrand University of Johannesburg, was making prospect excavations. The professor with his team followed Matthew, and in a few days extracted more than 200 human fossils belonging to two individuals of different age and showing mixtures of different traits, ones distinctive of austrolopithecines, other of humans. Prof. Berger classified the fossils as a new species, named Australopithecus sediba (Berger et al., 2010), and presented it as the last human ancestor, the closest one to Homo erectus/or H. ergaster. The site is named Malapa, and the fossils bringing level was accurately dated as $1.977 \mathrm{Ma}( \pm 0.002)$. This date, and the fact of leaving out of our ancestry the number of fossils classified as Homo habilis, some of them dated more than $2 \mathrm{Ma}$, provoked a controversy about the time and the evolutionary way that can be retained as ensured for the origin and the closest ancestors of all true humans.

Excuse me, for introducing here a note concerning nomenclature and taxonomy. I am convinced that genera Australopithecus, Paranthropus and Homo must be considered as joint in a zoological Family, not a subfamily, and consequently cited as "Hominidae" not "Hominini" as it is now currently written. These genera differ from all other primates - Pongo, Pan and Gorilla included - in the structure and functions of the whole vertebral column, pelvis, tarsus, in bipedal vertical walk and standing. Such an exceptional change in form and function must be taken into account, added to phylogeny, for classification, and deserves the taxonomic category of a Family within the Order Primates and the Superfamily Hominoidea: consequently cited as "hominids", no "hominins". The latter I feel obliged to consider wrong, and ask to revise the recently introduced nomenclature.

The skeletal parts of the adult female recovered in Malapa include: a) The almost complete mandible, b) one clavicle, one scapula and part of the other, c) portions of pelvis, d) several cervical, dorsal and lumbar vertebrae and the sacrum, e) half a dozen of ribs, not all entire, f) the humerus, ulna, radius and several carpal bones of the right side, and some fragments of left, g) all right metacarpal bones and phalanges, few of the left hand, h) right calcaneum and talus; few fragments of leg bones, without knee articular portions.

Those of the immature male are: a) The nearly complete skull, b) one incomplete clavicle, c) fragments of pelvis, d) nearly ten vertebrae, and a few fragments of both sides ribs, e) almost complete right humerus, and few more portions of arms and hand, and f) part of a femur, most of right tibia, almost nothing of feet.

Well observed were in the female with small body her similarities with the australopithecines such as her long arm and the primitive calcaneum, together with human like wide pelvis, large birth channel, progressive talus, hand skeleton and teeth, and the both sides similarities also in the immature remains, as low cranial capacity, with frontal and face profile human-like, and a rather long leg. That is the evidence convincing Berger that Austrolopithecus sediba was the true and single intermediate between australopithecines and humans, so leaving $H$. habilis out of human ancestry, as a side branch or episode without succession, and consequently, the true origin of genus Homo happened less, no more than two million years ago, in South Africa, the "habilis" ancestry being left aside, as an "East-Side Story".

Berger is right emphasizing the risk of mistaking when one classifies as different species fragmentary fossils found in proximity of space and time, but showing isolate traits known in fossils of different localities. He also recognizes the difficulties in comparing the more complete fossil record from Malapa with other maybe abundant but incomplete: the inferences will remain uncertain.

\section{CONTROVERSY ON THE CLOSEST ANCESTOR OF HUMANS}

The Berger's new version provoked, as could be expected, a reaction among the specialists, but the responses were multiple and different. In a recent chapter of Scientific American, June 2012, Kate Wong refers a summary of this new controversy on the precise authors and circumstances of human origin, with half a dozen of opinions (Wong, 2012). That of Bobe (2011) sustains as our ancestors, of genus Homo, those known by a good number of fossils around the lake Turkana (Kenya), more ancient than those of Malapa; Kimbel et al. (2004) support as the most ancient Homo the one known by the maxilla from Hadar (Ethiopia), dated 2.3 Ma, and the opinion on that certain traits of several body portions, even in separate fossils, can be convincing. The Meave Leakey suggestion that more than one independent evolutionary lines with similar trends may have been produced in East Africa is not sufficient to clarify the real evolutionary tree, nor to decide who was in fact the true last ancestor of the human branch (Wood \& Leakey, 2011), and, on the other hand, the question has promoted more new sites prospecting and excavations, and more deep research on the already known fossils of the human family on different scientific approaches.

A meeting of palaeoanthropologists in Minneapolis included a detailed deep comparative revision in form, size and function of $A$. sediba pelvis with evolutionary inferences 
(Churchill et al., 2011), and of forelimb (Macías et al., 2011) also a quest about the decisive influence, either generic or adaptative, on the differences that can be observed in mandibles of primitive Homo fossils and their possible or presumed ancestors (Schroeder \& Ackermann, 2011).

Another relevant research field with heavy weight on the solution and discussion is the geochronological situation of the questioned fossils. In the present fossil record Australopithecus africanus is known in South Africa between 2.8-2.4 Ma. Less than 2.0 Ma are aged the $P$. robustus known in South Africa, and the A. sediba of Malapa dated 1.97 Ma. A complex scenario is proposed by Pickering et al. (2011) supporting the A. sediba as the only well known and guaranteed last ancestor of genus Homo, in a mosaic or "adaptative radiation" occurred near 2.0 Ma. Their strongest argumentation consists on a revision of chronometric dates. The $A$. sediba age is 1.977 Ma. The most ancient $H$. erectus or ergaster fossils (Wood, 1991) from Koobi-Fora are aged 1.90-1.88 Ma (Leakey et al., 2012); reading White (1995) the date $1.90 \mathrm{Ma}$ is probable, 1.75 Ma is sure. Pickering et al. (2011) reject the references of $H$. habilis/or $H$. rudolfensis with more than 2.0 Ma, maybe with the exception of the maxilla AL666.1, 2.33 Ma, with Homo traits, and conclude that the A. sediba fossils are younger but penecontemporaneous of those named "habilis" or "rudolfensis", and that anyone that could be considered ancestors of $H$. erectus must be classified as Australopithecus.

On the other hand, Australopithecus afarensis in East Africa is dated between 4-3 Ma, or near 3.8 Ma; Kenyanthropus platyops between 3.53-3.3 Ma; Paranthropus aethiopicus between 2.7-2.3 Ma; A. garhi between 2.5-2 Ma, with conservative traits; $P$. boisei, from 2.3 to $1.4 \mathrm{Ma}$; Homo habilis (sensu lato, including $H$. rudolfensis) from 2.4 to 1.6 Ma; H. ergaster, 1.87 to $1.5 \mathrm{Ma}$ (Wood \& Leakey, o.c.).

May we observe that a mosaic or radiation with new progressive traits in fossil hominids around $2 \mathrm{Ma}$ is proved and cannot be rejected, but this radiation is first genetic, then adaptative before being selected. Hence, the mosaic should have been living before the selection of a lineage as the new species and even genus in the case. The explosion of new traits could and must have been produced well before $2 \mathrm{Ma}$. Another solid proof in favour of fossils from East-Africa can be the existence of lithic tools repeated in number of sites and beds dated as more than 2.0 Ma, even near and or more than 2.5 Ma (see Aguirre, 2003).

May we recognize that all these opinions are based on observed facts, and the proposed phylogenetic trees must be taken into consideration, at least as alternative hypotheses. But to correctly evaluate these evolutionary models and uncover the most convincing it is necessary to avoid the idea of sudden, abrupt changes between two different species, and to take into account what is real and evident, observed in the process of change or evolution from one species to another.
In many cases a great diversity of traits or trait ensembles are observed into not only one single species but also within one race, or tribe, or a family. In other cases, one single different trait or color point, or single change in time of sexual maturity forces the isolation and definition of two different species. But it is quite frequent and common, at least in complex animals, that new diverse traits are present in diverse individuals of the same ancestral species, or even in different related species along a time span before, or even after the isolation of a new species, or even long before the extinction of the ancestor or mother species.

\section{CONCLUSIONS}

In my opinion, the opposite hypotheses must be reexamined, in three aspects:

First, the solid consideration of the fact that evolution from one to other species, and between genera must not be supposed to occur suddenly nor in a short time but along a process of changes that is better supposed to take time. That is to say, the exclusion of Homo habilis/rudolfensis, as ancestor of $H$. erectus or as correct species of genus Homo, is not better grounded than its assertion.

Second, a solid ground for a reliable hypothesis is the conviction that a time margin is normal for a morphologic and functional evolution, within an ensemble of populations. This margin with early appearance of distinctive human traits mixed with other old primitive, may sustain the classification or not as a distinct species, or even genus, before the prevalence of the new ones becomes exclusive, or just dominant.

Third, the doubts can be consistently solved with new comparative study of the known fossils classified as $H$. habilis and/or $H$. rudolfensis, and of course with "new and better" fossil assemblages. I think that several facts and arguments must be reexamined before taking a secure decision.

A phase of diversification of australopithecines is obvious between some less than $4 \mathrm{Ma}$ and 3.5 Ma. It was followed by a more remarkable one between some more or some less than $2.5 \mathrm{Ma}$ and near 2 or $1.9 \mathrm{Ma}$, when A. africanus was succeeded by A. garhi, P. aethiopicus, A. sediba, $H$. habilis and maybe $H$. rudolfensis. In both events, mainly in the second one, the selective factor of environmental aridity crisis, with tropical forest recession is evident.

The most successful branch was that of humans, with lesser change in masticatory apparatus and great increase of brain size and consequent progress in intelligence and its translation into tools using and making. First more simple lithic tools of Mode 1 are known in East-Africa since about, or little more than 2.5 Ma (as said above). The only argument against the date of AL-666 made by 
Berger and colleagues is falsified by the fact that the stratigraphic unit where it was found laying contains no sediment younger than 2 Ma.

The end of this evolutionary phase was spectacular, not only for the number of "species" originated and for the immense functional progress in life, tool-making, use of environment and social organization, but also because, just in the very early years of $H$. erectus/ergaster; one of its initial tribes decided to overcome the aridity crises, not improving industry as the mean for finding food, but leaving Africa in search of new fertile lands, so initiating the extension of humankind to Eurasia. That took about one million years with little progress in lithic techniques.

The tribes of the new species remaining in Africa in dry open mountains and valleys survived with lithotechnical progress. Very soon, nearly $1.7 \mathrm{Ma}$, they got the Lower Palaeolithic Mode 2, the industry of large heavy tools: bifaces, trihedral picks and cleavers. This high industrial level was introduced in Europe no much before 0.7 Ma, nearly one million years later.

A well known fact that consistently proofs the scenario of a sufficient long-time for appearing and prevailing of individuals showing characteristic traits of the two human successive "species", the one decaying and the other prevailing, is well known in the Dmanisi (Georgia) site. Here the excavations in 1991 to 2002 furnished among many other bone fossils and tools, four well preserved skulls and four mandibles difficult to classify, even so very well, completely studied, very near each other in space and time, very close to a lava bed dated little less than 1.8 MabP. Some of them could be classified as $H$. ergaster, other as $\mathrm{H}$. habilis (Agustí \& Lordkipanidze, 2005). Classifying all of them as a new species is not correct; nor both as $H$. habilis, since that would force to accept a repeated origin of the same species $H$. erectus from $H$. habilis in Africa and in Eurasia.

More consistent would be the scenario of a most progressing mosaic species with some intermediate traits still persisting in the new $H$. erectus, or maybe better recognizing the intermediate populations since more than $2 \mathrm{Ma}$, showing traits sufficient since less than 1.9 Ma, and more progressive traits at least in several individuals or tribes, that became dominant around 1.8 Ma in populations that were detached as the new species: sufficient for classifying transitional species as the first one in the genus Homo, namely $H$. habilis. A very similar and contemporary genetic trend is the one evident in A. sediba, but its continuity with the earliest known $H$. erectus/ergaster is not so evident as that of the East-African $H$. habilisrudolfensis. The phylogeny Australopithecus africanusHomo habilis-Homo erectus is the most and the only one consistent with the known fossil record.

\section{ACKNOWLEDGEMENTS}

The absence of Nieves López is a very hard feeling also in her second home, the university labs and classrooms, but I am sure her person, devoted to increase life history knowledge and to her family, friends and student progress, is and shall be living out of time and space. May I dedicate to her memory and her personality, jointly with you all, these recent considerations on circumstances of humankind origins. Finally, the author is indebted and grateful to Guillermo Navalón (Universidad Autónoma de Madrid) and Jorge Morales (Museo Nacional de Ciencias Naturales, CSIC) for his essential cooperation to this work.

\section{REFERENCES}

Aguirre, E. 2003. Primeros desarrollos de la mente humana. Revista de la Real Academia de Ciencias Exactas, Físicas y Naturales, 97, 254-269.

Agustí, J. \& Lordkipanidze, D. 2005. Del Turkana al Cáucaso. National Geographic RBA Libros, S.A., Barcelona.

Berger, L.R., de Ruiter, D.J., Churchill, S.E., Schmid, P., Carlson, K.J., Dirks, P.H.G.M. \& Kibii, J.M. 2010. Australopithecus sediba: A new species of Homo-like Australopith from South Africa. Science, 328, 125-204.

Bobe, R. 2011. Fossil Mammals and Paleoenvironments in the Omo-Turkana Basin. Evolutionary Anthropology, 20, 254-263.

Churchill, S.E., Kíbii, J.M., Shmid, P., Karlson, K.J., Redd, N.D., de Ruiter, D.J. \& Berger, L.R. 2011. Sacroacetabular Load Transfer and Sacral Stabilization in the Pelvis of Austrolopithecus sediba. Paleoanthropology Society Meeting Abstracts, Minneapolis, Mn, 12-13, N3no page number.

Kimbel, W.H., Rak, Y. \& Johanson, D.C. 2004. The skull of Australopithecus afarensis. New York, Oxford University Press.

Leakey, M.G., Spoor, F., Christopher Dean, M., Feibel, C.S., Antón, S.C., Kiarie, C. \& Leakey, L.N. 2012. New fossils from Koobi Fora in northern Kenya confirm taxonomic diversity in early Homo. Nature, 488: 201-204.

Macías, M.E., Churchill, S.E. \& Berger, L.R. 2011. Morphological Analysis of the Elbow Joint of Austrolopithecus sediba. Paleoanthropology Society Meeting Abstracts, Minneapolis, Mn, 12-13, N3- no page number.

Pickering, R., Dirks, P.H.G.M., Jinnah, Z., de Ruiter, D.J., Churchill, S.E., Herries, A.I.R., Woodhead, J.D., Hellstrom, J.C. \& Berger, L. R. 2011. Australopithecus sediba at $1.977 \mathrm{Ma}$ and implications for the origins of the Genus Homo. Science, 333, 1421-1423.

Schroeder, L. \& Ackermann, R.R. 2011. A Re-Evaluation of Mandibular Variation in Early Homo. Paleoanthropology Society Meeting Abstracts, Minneapolis, Mn, 12-13, N3no page number. 
White, T.D. 1995. African omnivores, Global Climate Change and Plio-Pleistocene Hominids and Suids. In: Paleoclimate and Evolution with Emphasis on Humans Origins (eds. Vrba, E.S., Denton, G.H., Partridge, T.C. \& Burckle, L.H.). Yale University Press, New Haven, 356-384.

Wong, K. 2012. "First of Our Kind”. Scientific American, 306, 30-39. (Versión Española “El origen del género Homo”. Investigación y Ciencia, 429, junio 2012, 16-25).
Wood, B.A. 1991. Koobi Fora Research Project, vol. 4: Hominid Cranial remains. Oxford University Press. Oxford.

Wood, B. \& Leakey, M. 2011. The Omo-Turkana Basin fossil Hominins and their contribution to our understanding of Human Evolution in Africa. Evolutionary Anthropology, 20, 264-292. 
